\title{
Acacia bark residues as filler in polypropylene composites
}

\author{
Ticiane Taflick ${ }^{1,2}$, Élida Gonçalves Maich ${ }^{3}$, Laís Dias Ferreira ${ }^{1}$, Clara Isméria Damiani Bica', \\ Silvia Rosane Santos Rodrigues ${ }^{2}$ and Sônia Marlí Bohrz Nachtigall ${ }^{1 *}$
}

\author{
'Universidade Federal do Rio Grande do Sul, Porto Alegre, RS, Brasil \\ ${ }^{2}$ Instituto Federal de Educação, Ciência e Tecnologia Sul-rio-grandense, Sapucaia do Sul, RS, Brasil \\ ${ }^{3}$ Universidade La Salle, Canoas, RS, Brasil \\ *sonia.nachtigall@ufrgs.br
}

\begin{abstract}
Large amounts of acacia bark residues are produced each day after tannin extraction with hot water, being generally burned. This by-product was chemically characterized and used as filler in polypropylene (PP) composites, considering different particle sizes and concentrations. The materials produced by melt blending had their mechanical and thermal properties evaluated. It was verified that, even containing a significant amount of extractable compounds, the acacia bark particles can produce PP composites with higher impact properties, higher crystallization temperature and higher degradation temperature in comparison to the polymer matrix.
\end{abstract}

Keywords: composites, natural fibers, impact properties, tensile properties, thermal degradation.

\section{Introduction}

Polymers filled with lignocellulosic materials have been employed since the 80 's in the form of wood plastic composites (WPCs). Natural fibers obtained from plants are environmentally friendly alternatives as reinforcement for synthetic polymers mainly due to their relative high strength and stiffness, low cost, low density, low $\mathrm{CO}_{2}$ emission, biodegradability and renewable character ${ }^{[1]}$. They are non-abrasive during processing, allowing the improvement of stiffness and strength in thermoplastics ${ }^{[2,3]}$. Although WPCs have been widely studied ${ }^{[4-7]}$ a survey of the literature reveals that the use of bark particles as thermoplastic fillers has not been extensively evaluated.

The bark is the outer part of the tree trunks and branches. It shows different chemical composition and is less fibrous than the woody parts of the trees ${ }^{[8,9]}$. As a residue from industries, the bark is mostly used for thermal energy production. Its use as an alternative raw material for WPCs might result in better utilization of such natural resource.

The black acacia (Acacia mearnsii De Wild) is a tree species from Australia which grows fast and with a plentiful of uses (bark and wood). It is one of the most important cultivated trees in the state of Rio Grande do Sul, Brazil. The hot water extract obtained from black acacia bark is rich in tannins, which are polyphenols largely used for leather tanning, water treatment, and for pharmaceutical and chemical products filtering ${ }^{[9]}$. Nowadays, the bark residue obtained after tannin extraction is an environmental problem and it has been generally burned. Thus, the use of black acacia bark as filler in polymers can be an alternative to an environmental damage caused by the tannin industry, leading to both economic and environmental benefits.

Among the commodities used in the manufacture of WPCs, polypropylene (PP) is very important because of its low cost, specific low weight and good mechanical properties for non-structural applications ${ }^{[10]}$. It has been

shown that both bark and wood flour significantly increase the mechanical strength of thermoplastics, irrespectively of the botanical species ${ }^{[1]}$. However, the effect of bark particles is less pronounced. Safdari et al. ${ }^{[11]}$ attributed this behavior to the presence of fines, to the low aspect ratio of bark particles and to the lower intrinsic fiber strength of bark fibers compared to wood fibers.

The present study agrees with the global trend regarding the decrease in consumption of raw materials from non-renewable sources and with the efforts to reduce global warming. So, we have studied the mechanical and thermal properties of PP composites prepared with black acacia bark after tannin extraction. Polypropylene functionalized with maleic anhydride (MAPP) was used as a compatibilizer to improve the adhesion between the matrix and the filler ${ }^{[5,12-14]}$.

\section{Experimental}

\subsection{Materials}

The black acacia bark, after tannin extraction with hot water followed by compression, was supplied by SETA S/A - Extrativa Tanino de Acácia localized in Estância Velha, Brazil. Sulfuric acid, hexane and ethanol p.a. from Fmaia, Brazil, were used as received. Isotactic PP (MFI $=3.5 \mathrm{~g} / 10 \mathrm{~min}$; $\mathrm{d}=0.905 \mathrm{~g} / \mathrm{cm}^{3}$ ) was supplied by Braskem S.A.. PP modified with maleic anhydride (MAPP, $1 \%$ maleic anhydride) Polybond 3200 from Uniroyal Chemical was used as coupling agent.

\subsection{Filler conditioning}

The black acacia bark was dried in a first step for $12 \mathrm{~h}$, at $60{ }^{\circ} \mathrm{C}$, and in a second step at $70^{\circ} \mathrm{C}$, in a dryer oven, under low pressure, until constant weight. The material was triturated using a cryogenic rotatory mill, and separated using ASTM standard mesh sieves. Three different ranges 
of particle size were used: short (106-212 $\mu \mathrm{m})$, medium $(212-425 \mu \mathrm{m})$ and large $(425-600 \mu \mathrm{m})$.

\subsection{Preparation of the composites}

The composites were prepared in a melt mixer Haake, Rheomix 600p, at $50 \mathrm{rpm}$, for $8 \mathrm{~min}$, at $180^{\circ} \mathrm{C}$, according to the compositions shown in Table 1. All components were introduced at the same time into the mixer.

Films were prepared using a hydraulic press Carver, Monarch series, $3710 \mathrm{C}$ model, by pre-heating samples at $180^{\circ} \mathrm{C}(5 \mathrm{~min})$ followed by pressing at $2500 \mathrm{kgf}(5 \mathrm{~min})$. Injected specimens for tests were obtained using a Thermo Scientific MiniJet II, by injecting small composite pieces at $180^{\circ} \mathrm{C}$. The injection pressure used was $250 \mathrm{bar}$, with $5 \mathrm{~s}$ injection and mould temperature at $40^{\circ} \mathrm{C}$.

\subsection{Bark acacia characterization}

The as-received acacia bark particles were imaged using a conventional camera. SEM images of the ground acacia bark particles were done using a JEOL ${ }^{\circledR}$ microscope JSM 6060 , operating at $20 \mathrm{kV}$. The particles were attached to an aluminum stub and sputtered with gold to eliminate electron charging effects.

The content of extractives in acacia bark was determined through Soxhlet extraction with hexane, ethanol and water, in this sequence, according to TAPPI T 204 (adapted). The lignin content was determined by the method described in TAPPI T 222, by measuring the insoluble fraction in sulfuric acid. The ash content was determined by calcination in a muffle furnace Provecto Analítica MFLO1000, according to TAPPI T 211: the material was gradually heated to $525^{\circ} \mathrm{C}$, and then left at that temperature until constant weight. The holocellulose content (cellulose + hemicellulose) was determined by difference. Ground samples, in triplicate, were dried out until constant weight to determine the moisture content.

$\mathrm{X}$-ray diffraction analysis was performed using a Siemens D-500 diffractometer, using an incident X-ray of $\mathrm{CuK} \alpha$ with wavelength of $1.54 \AA$. The Segal method ${ }^{[15]}$ was used to calculate the crystallinity of cellulose present in the sample according to Equation 1, where $\mathrm{X}_{\mathrm{C}}$ is the sample crystallinity. $I_{200}$ is the height of the 200 peak, which represents both crystalline and amorphous cellulose and $\mathrm{I}_{\mathrm{AM}}$ is the lowest height between the 200 and 110 peaks, which represents only the amorphous fraction.

$$
\mathrm{X}_{\mathrm{C}}=\left(\mathrm{I}_{200}-\mathrm{I}_{\mathrm{AM}} / \mathrm{I}_{200}\right) \times 100 \%
$$

\subsection{Characterization of the composites}

Samples for Izod impact tests were prepared by injection moulding according to ASTM D256, in rectangular samples with $63.5( \pm 2) \mathrm{mm}$ length, $12.7( \pm 0.2) \mathrm{mm}$ width and $3.18 \mathrm{~mm}$ thick. The notched was formed at $45^{\circ}$ with a depth of $2.45 \mathrm{~mm}$.

Tensile tests were performed according to ASTM D638 in a Universal Testing Machine EMIC DL 10000, using injected samples with $62.6 \mathrm{~mm}$ of length.
Calorimetric analyses were performed using a TA Instruments Q20, under inert atmosphere, at $10{ }^{\circ} \mathrm{C} / \mathrm{min}$ heating rate, from room temperature to $180^{\circ} \mathrm{C}$. The samples were kept at this temperature for $3 \mathrm{~min}$ and then were cooled down to $25{ }^{\circ} \mathrm{C}$ at $60^{\circ} \mathrm{C} / \mathrm{min}$ and heated again to $200{ }^{\circ} \mathrm{C}$ at $10^{\circ} \mathrm{C} / \mathrm{min}$. The reported thermal data were taken during the cooling and second heating cycles. The degree of crystallinity (Xc, \%) was determined from the second melting enthalpy considering the melting enthalpy of $100 \%$ crystalline PP as $209 \mathrm{~J} / \mathrm{g}^{[16]}$.

Thermogravimetric analyses were performed using a TA Instrument $\mathrm{Q} 50$, at $20^{\circ} \mathrm{C} / \mathrm{min}$ heating rate, from 50 to $800{ }^{\circ} \mathrm{C}$, under inert atmosphere.

\section{Results and Discussion}

\subsection{Filler characterization}

\subsubsection{Morphology}

The raw acacia bark contained a mixture of large flat particles and thin fibers, as shown in Figure 1a. Because of this fact, some particles show high aspect ratio $(>50)$ while others have aspect ratio around one.

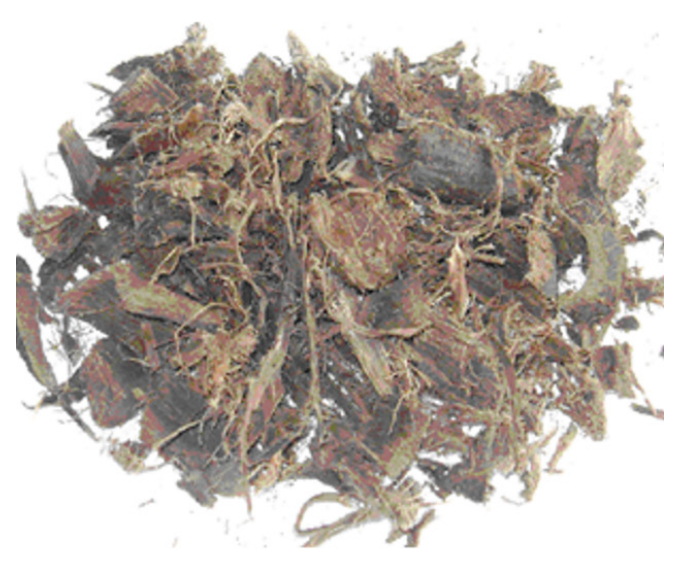

(a)

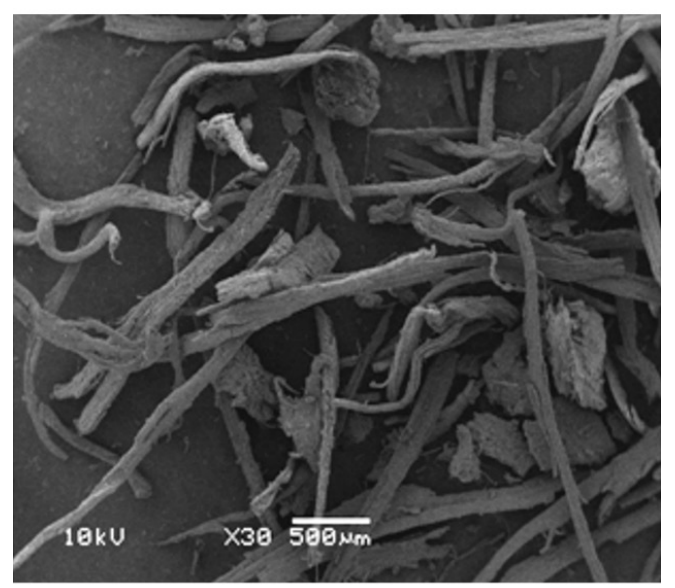

(b)

Figure 1. (a) Image of the as-received acacia bark particles; (b) SEM micrograph of ground acacia bark particles (sample LF). 
Figure 1b (Sample LF) shows that although a significant amount of fines could be produced during grinding, they were not observed in the samples. This image shows many fibrous structures together with a minor fraction of irregular-shaped small particles. Besides, the surface of the particles seemed to be very smooth probably due to the hot water treatment during tannin extraction, which could remove small components originally adhered to the material.

\subsubsection{Chemical composition of acacia bark}

Studies in the literature have shown that some kinds of barks present lower cellulose content, higher lignin content and higher hot and cold water extractives than their woods ${ }^{[17,18]}$. They may still have high inorganic content, mainly due to the presence of silica, which results in high ash amount ${ }^{[11]}$. The contents of extractives, holocellulose, lignin, ash and residual moisture in acacia bark particles were determined. The results are presented in Table 2.

As can be seen in Table 2, the percentage of extractives in acacia bark was relatively high $(26.3 \%)$. However, in comparison to poplar bark $(51 \%)^{[11]}$ it was low. As the acacia bark used had been previously submitted to hot water treatment during tannin extraction, part of the soluble material had been certainly removed. From the total extractives, $16.8 \%$ were soluble in organic solvent and $9.5 \%$ were soluble in water. The remaining water-soluble compounds could be now extracted due to the smaller size of the particles used. The low content of holocellulose $(42.5 \%)$ in black acacia bark reflects a low content of cellulose, when compared to common woods $(57-63 \%)^{[19]}$. However, these results come up well with findings in the literature for acacia $\operatorname{bark}^{[17]}$. The high lignin content $(20.5 \%)$ can potentially contribute to an excellent rigidity when compared to other bark fibers ${ }^{[20]}$. The low level of ash found for acacia bark in our study $(2.1 \%)$, indicates that this material shows low inorganic content.

Table 1. Formulations of the composites.

\begin{tabular}{ccccc}
\hline Identification & $\begin{array}{c}\text { PP } \\
(\%, \mathbf{w t})\end{array}$ & $\begin{array}{c}\text { MAPP } \\
(\mathbf{\%}, \mathbf{w t})\end{array}$ & $\begin{array}{c}\text { Filler } \\
\text { content } \\
(\mathbf{\%}, \mathbf{w t})\end{array}$ & $\begin{array}{c}\text { Filler size } \\
(\boldsymbol{\mu m})\end{array}$ \\
\hline PP* & 98 & 2 & 0 & - \\
SF-10 & 88 & 2 & 10 & $106-212$ \\
MF-10 & 88 & 2 & 10 & $212-425$ \\
LF-10 & 88 & 2 & 10 & $425-600$ \\
LF-20 & 78 & 2 & 20 & $425-600$ \\
LF-30 & 68 & 2 & 30 & $425-600$ \\
\hline
\end{tabular}

Table 2. Chemical composition of black acacia bark.

\begin{tabular}{lc}
\hline & Black acacia bark \\
\hline Extractives (\%) & 26.3 \\
Holocellulose (\%) & 42.5 \\
Lignin (\%) & 20.5 \\
Ash (\%) & 2.1 \\
Moisture (\%) & 8.6 \\
\hline
\end{tabular}

\subsubsection{X-ray diffraction}

Among the acacia bark components, only cellulose is crystalline. In this study, X-ray diffraction was used to evaluate the degree of crystallinity of cellulose in black acacia bark. Figure 2 shows that the major crystalline peaks of cellulose in acacia bark correspond to those found in materials exhibiting Cellulose I structure, where the peak around $2 \theta=22^{\circ}$ represents the $(200)$ crystallographic plane while the peak around $2 \theta=15^{\circ}$ is assigned to the $\left(\begin{array}{lll}1 & 0 & 1\end{array}\right)$ crystallographic plane ${ }^{[21]}$.

The crystallinity index calculated by Segal formula for black acacia bark was $60 \%$. Lower values of crystallinity have been found in the literature for other bark samples, such as $49.3 \%$ for Eucalyptus grandis, $43.4 \%$ for Pinus elliottii ${ }^{[19]}$ and $46 \%$ for Prosopis Juliflora barks ${ }^{[20]}$. This result suggests that acacia bark particles can be better used as filler in polymer composites since higher crystallinity is expected to improve mechanical properties.

\subsection{Preparation and characterization of composites}

Usually, commercial WPCs formulations contain particles that range in size from 180 to 1,700 micrometers ${ }^{[22]}$. Stark and Rowlands ${ }^{[23]}$ observed that smaller wood fibers performed significantly better than coarser fibers in both flexural and tensile strength and they attributed this trend to larger stress concentrations along the naturally weak interface of the larger wood particles. However, it was also found that systems containing larger fibers could show better performance than others containing smaller fibers if an interfacial agent was present ${ }^{[22]}$. In the present study, PP composites containing different sizes of acacia bark particles were prepared through melt processing, as shown in Table 1. Considering the addition of PP-g-MA as a coupling agent, the effect of different amounts of the larger-sized filler was investigated. A composition containing only the polymer and the coupling agent PPMA was also prepared for comparison.

\subsubsection{Mechanical properties}

It was found that the impact strength of the composites containing particles with size from 106 to $425 \mu \mathrm{m}$ exceeded that of the polymer matrix (Sample PP*, Figure 3), as a consequence of additional mechanisms of energy absorption

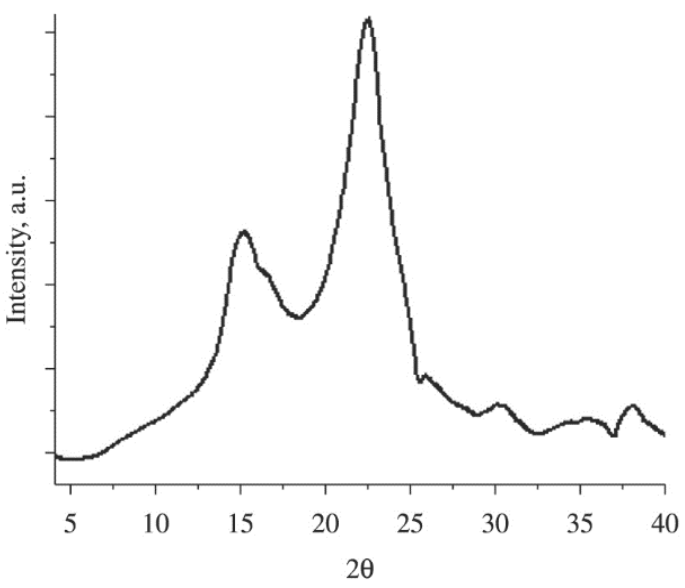

Figure 2. X-ray diffractogram of black acacia bark. 
during fracture. Probably, the small filler particles behaved as toughening centers, blocking crack propagation under impact and generating this interesting behaviour. However, the use of particles in the range of 426-600 $\mu \mathrm{m}$ decreased the impact strength to a value below that of the polymer matrix. Similar results were found by Saini et al. ${ }^{[17]}$, which encountered lower impact strength for larger acacia bark particles in PVC/acacia bark flour composites. According to Figure 3, the impact strength showed no dependence on the amount of filler used but it was solely related to the size

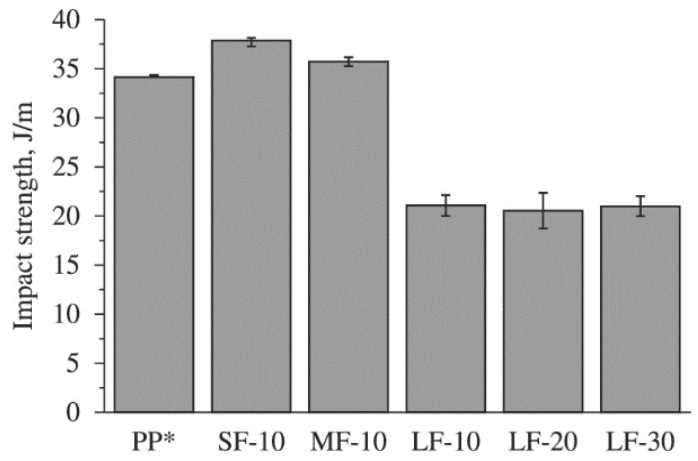

Figure 3. Effect of acacia bark particles on the Izod impact strength. of the filler particles. Larger particles provide more stress along their larger interface with the polymer, allowing the impact fracture to propagate more easily. In conclusion, PP composites prepared with the smaller acacia bark particles were more attractive for impact properties.

On the other hand, the tensile strength of all composites containing $10 \%$ of filler was kept similar to the polymer matrix, showing no dependence on the size of particles (Figure 4a). This indicates a good balance of filler dispersion and adhesion ${ }^{[24]}$. The addition of $2 \mathrm{wt} \%$ coupling agent was efficient in these systems. A distinct behavior was found for higher amounts of the large-sized particles (20 and 30\%), which showed somewhat lower tensile resistance. This is related to the presence of the filler itself and to the lower MAPP/filler ratio, since the MAPP content was kept constant in all compositions while the filler content was increased. In a previous study it was verified that, for PP composites containing $30 \%$ of several lignocellulosic fibers, the tensile strength increased when the concentration of MAPP was increased up to $10 \%{ }^{[13]}$.

A significant decrease of the Young modulus and elongation at break was found with the addition of the fillers in comparison to the base matrix ( $\left.\mathrm{PP}^{*}\right)$, according to Figures $4 \mathrm{~b}$ and $4 \mathrm{c}$. This behavior is partially due to the presence of the soluble molecules in the bark composition,

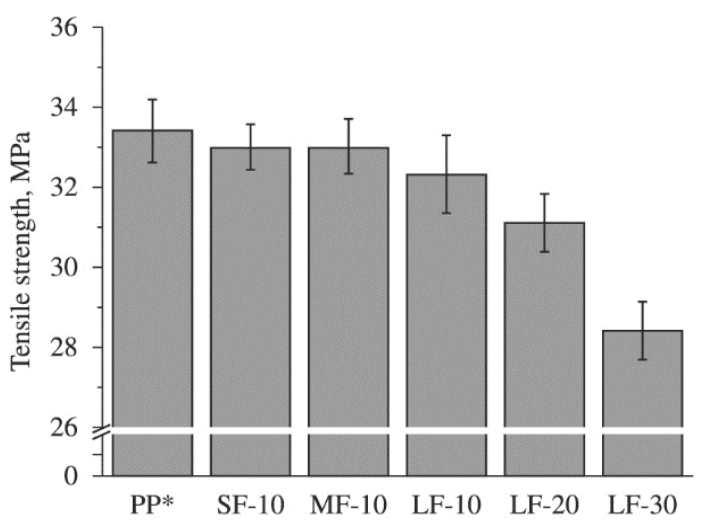

(a)

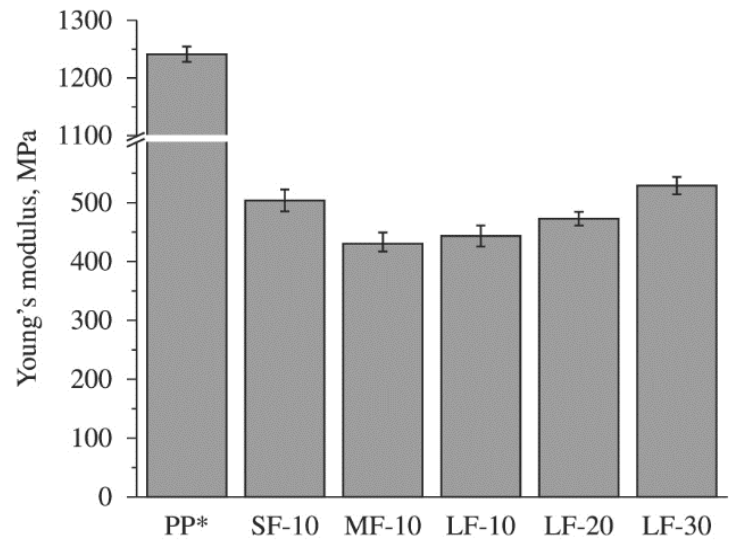

(b)

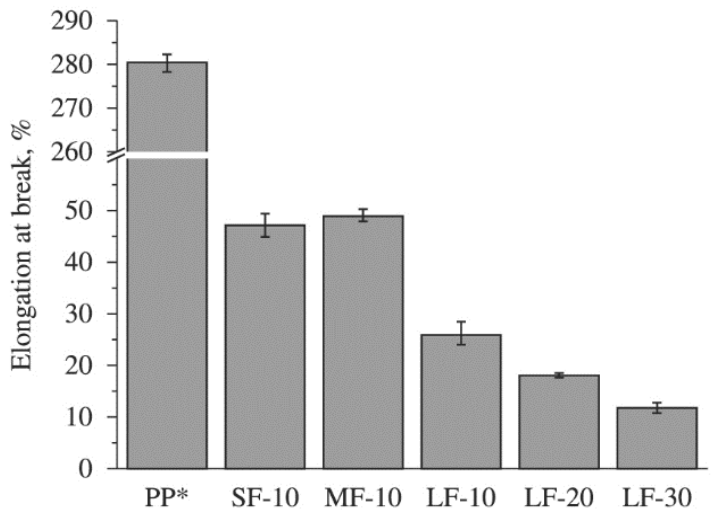

(c)

Figure 4. Tensile properties: (a) tensile strength; (b) Young's modulus; (c) elongation at break. 
represented by the solvent extractable fraction. Soluble materials decrease the ratio of structural components in the filler. Moreover, large amounts of extractives could cause a decrease in the polarity of the filler surface and a decrease in wettability, limiting the PPMA performance ${ }^{[25]}$. Saini et al. ${ }^{17]}$ found similar results in PVC/acacia bark composites having acacia bark particle sizes in the range 100-150 $\mu \mathrm{m}$. Considering elongation at break, it was observed that the compositions containing small and medium-size particles behaved better. According to the literature ${ }^{[1]}$, short and tiny fibers (average particle size $0.24-0.35 \mathrm{~mm}$ ) should be preferred in polymer composites, since they provide higher specific surface area and the fibers are distributed more homogeneously compared to composites with long fibers. In fact, these materials do not show properties for use in high performance applications, but they can be used in specific applications where the mechanical strength is not so important, such as in decoration and other popular goods.

\subsubsection{Thermal properties}

Table 3 presents the thermal data obtained by DSC: crystallization temperature $\left(\mathrm{T}_{\mathrm{C}}\right)$, melting temperature $\left(\mathrm{T}_{\mathrm{m}}\right)$, melting enthalpy $\left(\Delta \mathrm{H}_{\mathrm{m}}\right)$ and crystallinity $\left(\mathrm{X}_{\mathrm{C}}\right)$.

PP melting temperature did not change in the composites, indicating that the crystalline structure of the polymer remained unaltered. However, the addition of filler increased polymer $T_{C}$ and $X_{C}$, probably due to an effect of nucleation. High crystallization temperature and crystallinity are interesting properties for thermoplastic processors since they reduce the production time, saving costs. The crystalline fraction of PP in all composites was similar.

Representative TG and DTG curves are presented in Figure 5. Table 4 shows the temperatures of maximum degradation rates $\left(\mathrm{T}_{\max }\right)$ and the percentage of residue remaining at $800{ }^{\circ} \mathrm{C}$ in the samples.

A close look at the curves in Figure 5 shows that the filler starts to degrade at temperatures lower than the polymer matrix. The weight loss of acacia bark below $100{ }^{\circ} \mathrm{C}$ is explained by water loss and this event was not observed in composites, indicating they are mainly

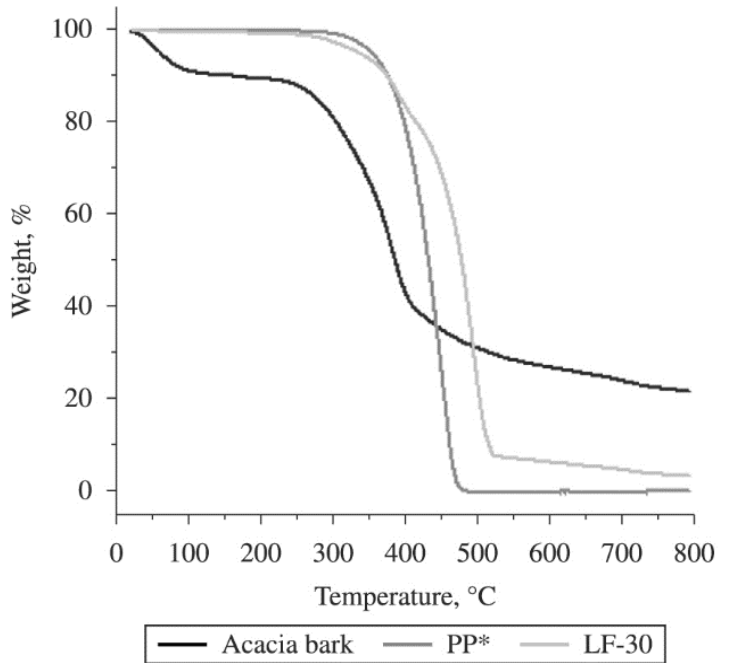

hydrophobic in nature. According to Yang et al. ${ }^{[26]}$ the peak at $382{ }^{\circ} \mathrm{C}$ can be attributed to the maximum degradation rate of cellulose. The shoulder at the left of this peak is attributed to hemicellulose. Lignin decomposition starts at relatively low temperature $\left(\sim 170^{\circ} \mathrm{C}\right)$, with low mass loss, and it happens on a wide range of temperature extending approximately to $600{ }^{\circ} \mathrm{C}^{[21]}$.

For the polymer matrix it is seen that the degradation happens in one step with the maximum rate occurring near $450{ }^{\circ} \mathrm{C}$. This maximum can be related to the breaking of $\mathrm{C}-\mathrm{C}$ bonds in PP chains ${ }^{[27]}$. The presence of MAPP did not show any additional important degradation event. Curves in Figure 5 clearly indicate that PP increased its thermal stability after compounding. An increase of $42{ }^{\circ} \mathrm{C}$ in the highest peak of the weight loss derivative curve for the composite containing $30 \%$ of large size fillers was observed

Table 3. Thermal properties of the composites.

\begin{tabular}{ccccc}
\hline Sample & $\begin{array}{c}\mathbf{T}_{\mathbf{m}}{ }^{(\mathbf{1})} \\
\left({ }^{\circ} \mathbf{C}\right)\end{array}$ & $\begin{array}{c}\mathbf{T}_{\mathbf{C}}{ }^{(2)} \\
\left({ }^{\circ} \mathbf{C}\right)\end{array}$ & $\begin{array}{c}\mathbf{X}_{\mathbf{C}}{ }^{(3)} \\
(\mathbf{\%})\end{array}$ & $\begin{array}{c}\Delta \mathbf{H}_{\mathbf{m}} \\
(\mathbf{J} / \mathbf{g})\end{array}$ \\
\hline PP* & 166.5 & 103.5 & 38 & 80 \\
SF-10 & 166.6 & 106.9 & 46 & 86 \\
MF-10 & 166.2 & 106.0 & 46 & 87 \\
LF-10 & 166.2 & 105.4 & 45 & 84 \\
LF-20 & 166.9 & 106.2 & 44 & 74 \\
LF-30 & 166.7 & 109.5 & 46 & 68 \\
\hline
\end{tabular}

${ }^{(1)}$ Maximum of the melting peak. ${ }^{(2)}$ Onset of the crystallization peak. ${ }^{(3)}$ Degree of crystallinity.

Table 4. Thermal data obtained from TGA (under nitrogen).

\begin{tabular}{ccc}
\hline Sample & $\begin{array}{c}\mathbf{T}_{\mathbf{m a x}} \\
\left({ }^{\circ} \mathbf{C}\right)\end{array}$ & $\begin{array}{c}\text { Residue at 800 } \\
{ }^{\circ} \mathbf{C}\end{array}$ \\
\hline Acacia bark & 382 & 22.40 \\
PP* & 453 & 0.06 \\
SF-10 & 464 & 1.60 \\
MF-10 & 455 & 1.70 \\
LF-10 & 459 & 1.60 \\
LF-20 & 470 & 1.90 \\
LF-30 & 495 & 3.70 \\
\hline
\end{tabular}

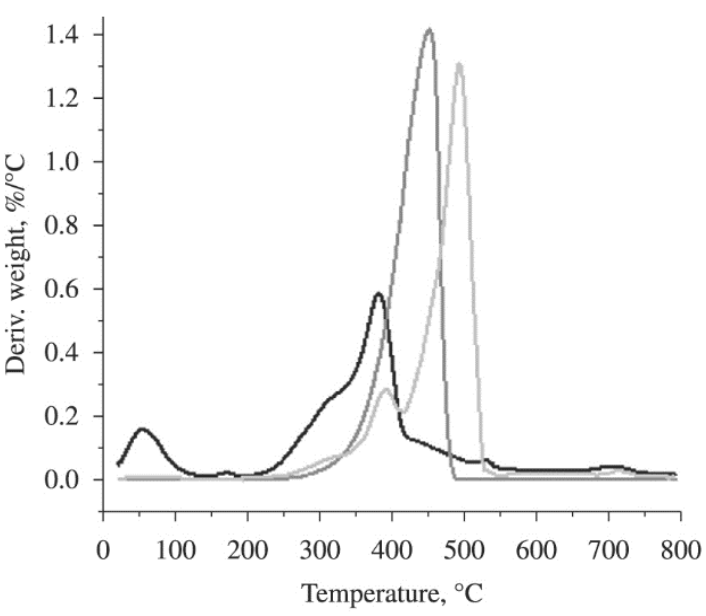

- Acacia bark $\longrightarrow$ PP* LF-30

Figure 5. TG and DTG curves of acacia bark, PP* and composite LF-30. 
(Table 4). We can attribute these results to the restriction of the polymer chains slippage in the presence of the fillers, which makes the mobility of the active species during degradation more difficult.

High residual mass was found for the acacia bark at the end of the analysis $(22.40 \%)$. This is probably related to an incomplete degradation of the filler components at $800^{\circ} \mathrm{C}$, under nitrogen. In accordance to this value, the residual mass of the composites increased with the content of the filler. However, the mass of residues in the composites was not as high as expected considering the filler amount, meaning that the smaller dimensions of the particles in the composites favored their degradation.

\section{Conclusions}

The results showed that PP composites prepared with black acacia bark particles after tannin extraction may have interesting properties, such as higher impact resistance, higher crystallization temperature and higher thermal stability than the matrix, depending on the amount and size of the filler used. Composites prepared with $10 \%$ acacia bark particles with sizes ranging from 106 to $425 \mu \mathrm{m}$ showed better properties than those prepared with larger particles (425-600 $\mu \mathrm{m}$ ) and higher amount (up to 30\%). As a bark raw material, these fillers contain high amount of extractable compounds that negatively affect the rigidity and the plasticity of the composites. However, the tensile strength was kept unaltered for the best compositions. Due to this fact, they can be suitable for use in non-structural applications, such as in decoration, sound isolation and household goods, with the advantages of reducing the environmental impact of using synthetic polymers and adding value to a waste product formed after tannin extraction from black acacia bark.

\section{Acknowledgements}

The authors thank to SETA S.A. for black acacia bark donation, to FAPERGS for scholarship and grants, to Federal University of Rio Grande do Sul, Sul-Rio-Grandense Institute for Education, Science and Technology and La Salle University.

\section{References}

1. Ashori, A. (2008). Wood-plastic composites as promising green-composites for automotive industries! Bioresource Technology, 99(11), 4661-4667. http://dx.doi.org/10.1016/j. biortech.2007.09.043. PMid:18068352.

2. Monteiro, S. N., Calado, V., Rodriguez, R. J. S., \& Margem, F. M. (2012). Thermogravimetric behavior of natural fibers reinforced polymer composites - An overview. Materials Science and Engineering A, 557, 17-28. http://dx.doi.org/10.1016/j. msea.2012.05.109.

3. Hristov, V. N., Lach, R., \& Grellmann, W. (2004). Impact fracture behavior of modified polypropylene/wood fiber composites. Polymer Testing, 23(5), 581-589. http://dx.doi. org/10.1016/j.polymertesting.2003.10.011.

4. Vianna, W. L., Correa, C. A., \& Razzino, C. A. (2004). Efeitos do tipo de poliestireno de alto impacto nas propriedades de compósitos termoplásticos com farinha de resíduo de madeira. Polimeros: Ciência e Tecnologia, 14(5), 339-348. http://dx.doi. org/10.1590/S0104-1428200400500012.
5. Correa, C. A., Fonseca, C. N. P., Neves, S., Razzino, C. A., \& Hage, E., Jr. (2003). Compósitos termoplásticos com madeira. Polímeros: Ciência e Tecnologia, 13(3), 154-165. http://dx.doi. org/10.1590/S0104-14282003000300005.

6. Nachtigall, S. M. B., Cerveira, G. S., \& Rosa, S. M. L. (2007). New polimeric-coupling agente for polypropylene/wood-flour composites. Polymer Testing, 26(5), 619-628. http://dx.doi. org/10.1016/j.polymertesting.2007.03.007.

7. Rodolfo, A., Jr., \& John, V. M. (2006). Desenvolvimento de PVC reforçado com resíduos de Pinus para substituir madeira convencional em diversas aplicações. Polímeros: Ciência e Tecnologia, 16(1), 1-11. http://dx.doi.org/10.1590/S010414282006000100005.

8. Harkin, J. M. \& Rowe, J. M. (1971). Bark and its possible uses (Note FP1-091). Madison: USDA Forest Service Research.

9. Charão, L. S. (2005). Polinização em Acacia Mearsii De Wild. Revista de Ciências Agro-Ambientais, 3, 92-109. Retrieved in 26 June 2014, from www.unemat.br/revistas/rcaa

10. Yamaji, F. M., \& Bonduelle, A. (2004). Utilização da serragem na produção de compósitos plástico-madeira. Revista Floresta, 34(1), 59-66. http://dx.doi.org/10.5380/rf.v34i1.2375.

11. Safdari, V., Khodadadi, H., Hosseinihashemi, S. K., \& Ganjian, E. (2011). The effects of poplar bark and wood content on the mechanical properties of wood-polypropylene composites. BioResources, 6(4), 5180-5192. Retrieved in 26 June 2014, from www.ncsu.edu/bioresources

12. Santos, E. F., Moresco, M., Rosa, S. M. L., \& Nachtigall, S. M. B. (2010). Extrusão de compósitos de PP com fibras curtas de coco: efeito da temperatura e agentes de acoplamento. Polimeros: Ciência e Tecnologia, 20(3), 215-220. http://dx.doi. org/10.1590/S0104-14282010005000036.

13. Moresco, M., Rosa, S. M. L., Santos, E. F., \& Nachtigall, S. M. B. (2010). Agrofillers in polypropylene composites: a relationship between the density and the mechanical properties. Journal of Applied Polymer Science, 117(1), 400-408. http:// dx.doi.org/10.1002/app.31602.

14. Becker, D., Kleinschmidt, A. C., Balzer, P. S., \& Soldi, V. (2011). Influência da sequência de mistura do PP-MA nas propriedades dos compósitos de PP e fibra de bananeira. Polímeros: Ciência e Tecnologia, 21(1), 7-12. http://dx.doi. org/10.1590/S0104-14282011005000012.

15. Thygesen, A., Oddershede, J., Lilholt, H., Thomsen, A. B., \& Stahl, K. (2005). On the determination of crystallinity and cellulose content in plant fibers. Cellulose, 12(6), 563-576. http://dx.doi.org/10.1007/s10570-005-9001-8.

16. Ayrilmis, N., \& Kaymakci, A. (2013). Fast growing biomass as reinforcing filler in thermoplastic composites: Paulownia elongate wood. Industrial Crops and Products, 43, 457-464. http://dx.doi.org/10.1016/j.indcrop.2012.07.050.

17. Saini, G., Bharwaj, R., Choudhary, V., \& Narula, A. K. (2010). Poly(vinyl chloride)-Acacia bark flour composite: effect of particle size and filler content on mechanical, thermal, and morphological characteristics. Journal of Applied Polymer Science, 117(3), 1309-1318. http://dx.doi.org/10.1002/app.29987.

18. Yemele, M. C. N., Koubaa, A., Cloutier, A., Soulounganga, P., \& Wolcott, M. (2010). Effect of bark fiber content and size on the mechanical properties of bark/HDPE composites. Composites. Part A, Applied Science and Manufacturing, 41(1), 131-137. http://dx.doi.org/10.1016/j.compositesa.2009.06.005.

19. Poletto, M., Zattera, A. J., Forte, M. M. C., \& Santana, R. M. C. (2012). Thermal decomposition of wood: influence of wood components and cellulose crystallite size. Bioresource Technology, 109, 148-153. http://dx.doi.org/10.1016/j. biortech.2011.11.122. PMid:22306076.

20. Saravanakumar, S. S., Kumaravel, A., Nagarajan, T., Sudhakar, P., \& Baskaran, R. (2013). Characterization of a novel natural 
cellulosic fiber from Prosopis juliflora bark. Carbohydrate Polymers, 92(2), 1928-1933. http://dx.doi.org/10.1016/j. carbpol.2012.11.064. PMid:23399239.

21. Popescu, M.-C., Popescu, C.-M., Lisa, G., \& Sakata, Y. (2011). Evaluation of morphological and chemical aspects of different wood species by spectroscopy and thermal methods. Journal of Molecular Structure, 988(1-3), 65-72. http://dx.doi. org/10.1016/j.molstruc.2010.12.004.

22. Ghallager, L. W., \& McDonald, A. G. (2013). The effect of micron sized wood fibers in wood plastics composites. Maderas, Ciencia y Tecnología, 15(3), 357-374. http://dx.doi. org/10.4067/S078-221X2013005000028.

23. Stark, N. M., \& Rowlands, R. E. (2003). Effects of wood fibers characteristics on mechanical properties of wood/polypropylene composites. Wood and Fiber Science, 35(2), 167-174.

24. Părpăriţă, E., Darie, R. N., Popescu, C. M., Uddin, M. D., \& Vasile, C. (2014). Structure-morphology-mechanical properties relationship of some polypropylene/lignocellulosic composites.
Materials \& Design, 56, 763-772. http://dx.doi.org/10.1016/j. matdes.2013.12.033.

25. Najafi, S. K., Kiaefar, A., \& Tajvidi, M. (2008). Effect of bark flour content on the hygroscopic characteristics of woodpolypropylene composites. Journal of Applied Polymer Science, 110(5), 3116-3120. http://dx.doi.org/10.1002/app.28852.

26. Yang, H., Yan, R., Chen, H., Zheng, C., Lee, D. H., \& Liang, D. T. (2006). In-depth investigation of biomass pyrolysis based on three major components: hemicelluloses, cellulose and lignin. Energy \& Fuels, 20(1), 388-393. http://dx.doi. org/10.1021/ef0580117.

27. Shebani, A. N., Van Reenen, A. J., \& Meincken, M. (2009). The effect of wood species on the mechanical and thermal properties of wood-LLDPE composites. Journal of Composite Materials, 43(11), 1305-1318. http://dx.doi.org/10.1177/0021998308104548.

Received: July 11, 2014

Revised: Nov. 20, 2014 Accepted: Dec. 18, 2014 